\title{
MEMBANGUN APLIKASI PERENCANAAN KARIR ONLINE BERBASIS WEB DENGAN MENGGUNAKAN METODE WATERFALL (STUDI KASUS PADA SMK X)
}

\author{
Warih Puspitasari ${ }^{1}$, Riesranty Nilandiny ${ }^{2}$ \\ 1,2Program Studi Sistem Informasi Fakultas Rekayasa Industri Universitas Telkom \\ Jl. Telekomunikasi No. 1, Terusan Buahbatu, Bandung 40257 Indonesia \\ warihpuspita@gmail.com, ries.ranty@gmail.com
}

\begin{abstract}
Abstrak-SMK X merupakan salah satu sekolah kejuruan yang didirikan dengan harapan dapat menjadi 'center of excellence' pendidikan menengah telekomunikasi di Indonesia dan lulusannya dapat mengisi lapangan kerja dalam bidang industri telekomunikasi serta dapat melanjutkan ke jenjang pendidikan yang lebih tinggi. SMK X memiliki badan konseling yang di dalamnya terdapat layanan bagi siswa untuk konseling dan perencanaan karir termasuk mengenai prosesi lowongan pekerjaan. Dalam melakukan aktivitas tersebut, terdapat beberapa masalah yang dihadapi antara lain aktivitas perencanaan karir tidak berjalan dengan maksimal dikarenakan keterbatasan waktu, tempat dan sumber daya manusia. Sementara untuk prosesi lowongan pekerjaan, masih memanfaatkan majalah dinding sebagai media untuk penyebaran informasi adanya lowongan pekerjaan dengan menempel kertaskertas. Permasalahan tersebut dapat diatasi dengan dibangunnya sebuah aplikasi secara online yang dapat membantu pihak BK untuk melakukan aktivitas antara lain proses konsultasi antara siswa dan guru melalui fitur pesan, informasi lowongan kerja dimana siswa bisa langsung mendaftarkan dirinya langsung untuk menjadi kandidat dari suatu perusahaan, dan juga adanya materi pelajaran serta artikel terkait karir yang dapat diunggah oleh para siswa. Sistem ini dibangun dengan metode waterfall. Dalam implementasinya, sistem berhasil mengatasi masalah yang ada. Untuk pengembangan selanjutnya, diharapkan sistem dapat lebih memenuhi fungsionalitas BK selain dari segi perencanaan karir.
\end{abstract}

Kata Kunci: SMK, metode waterfall, aplikasi karir online

\section{Pendahuluan}

Dunia kerja merupakan salah satu kelanjutan jenjang setelah menyelesaikan studi pendidikan, dalam menghadapi dan menjalaninya kelak perlu adanya sebuah persiapan yang matang. Harjono (1990 $)^{[1]}$ mengemukakan bahwa kesiapan siswa untuk memasuki dunia kerja adalah segala sesuatu yang harus disiapkan dalam melaksanakan sesuatu untuk mencapai suatu tujuan, ada beberapa faktor yang mempengaruhi kesiapan lulusan untuk memasuki dunia kerja seperti motivasi kerja, kemampuan kerja, kemampuan beradaptasi dengan pekerjaan, kemampuan beradaptasi dengan lingkungan, kemampuan berkomunikasi, penguasaan informasi tentang dunia kerja, persepsi tentang prospek karir, peluang untuk mendapatkan kesempatan kerja, dan gambaran pekerjaan yang dikerjakan di dunia kerja.

Karir dalam terminologi organisasi seringkali dikaitkan dengan kemajuan (advanced). Karir merupakan kebutuhan yang harus terus ditumbuhkan dalam diri seseorang tenaga kerja, sehingga mampu mendorong kemauan kerjanya. Pengembangan karir harus dilakukan melalui penumbuhan kebutuhan karir tenaga kerja, menciptakan kondisi dan kesempatan pengembangan karir serta melakukan penyesuaian antara keduanya melalui berbagai mutasi personal (Bambang Wahyudi, 2002) ${ }^{[2]}$.

Pendidikan menengah kejuruan adalah pendidikan jenjang menengah yang mengutamakan pengembangan kemampuan siswa untuk melaksanakan jenis pekerjaan tertentu dengan mengutamakan persiapan siswa untuk memasuki lapangan kerja serta mengembangkan sikap profesional. Sesuai dengan bentuknya, sekolah menengah kejuruan menyelenggarakan program-program pendidikan yang disesuaikan dengan jenis-jenis lapangan kerja ${ }^{[3]}$. Sebagai SMK yang kurikulumnya berfokus di bidang telekomunikasi, SMK $\mathrm{X}$ memiliki empat jurusan yaitu teknik transmisi, teknik switching, teknik jaringan akses dan teknik jaringan dan komputer. Dengan visi menjadi "center of excellence" pendidikan menengah telekomunikasi di Indonesia, SMK X mengharapkan agar nantinya lulusan mereka dapat mengisi lapangan kerja dalam bidang industri telekomunikasi. Agar dapat mencapai visi tersebut maka SMK X perlu mempersiapkan rencana karir siswa sedari awal, antara lain dengan cara mengintegrasikan konsep pendidikan karir dengan kurikulum di sekolah, yang kemudian diwujudkan dalam bentuk memberikan bimbingan karir.

Pada dasarnya bimbingan karir adalah suatu proses perkembangan yang berkesinambungan yang membantu siswa melalui perantara kurikuler yang dapat membantu dalam hal perencanaan karir, pembuatan keputusan, perkembangan keterampilan atau keahlian, informasi karir dan pemahaman diri. Untuk mengembangan kompetensi karir, diperlukan adanya indikator-indikator kompetensi karir. Dalam hal ini, 
maka diperlukan adanya peran konselor dan seluruh pihak sekolah maupun masyarakat. Konselor perlu menyusun program bimbingan dan konseling komprehensif sesuai dengan kultur atau budaya dan kebutuhan sekolah masing-masing.

Terdapat tiga indikator yang dapat digunakan untuk mengembangkan karir siswa, yaitu: ${ }^{[4]}$

1. siswa mampu memahami perkembangan dunia karir dan mengekplorasi kemampuan diri;

2. siswa mampu mempersiapkan diri (strategi) untuk proses karir di masa depan; serta

3. Siswa mampu mengatasi masalah dalam mempersiapkan karir dan mampu mengambil keputusan karir.

Dalam penelitiannya, Gysbers ${ }^{[5]}$ menjelaskan bahwa konselor perlu memberikan dukungan dalam program bimbingan karir secara komprehensif agar sesuai dengan kebutuhan siswa dan dapat memberikan kontribusi melalui pembelajaran kelas. Hal ini diharapkan agar proses bimbingan karir ini dapat memberikan nilai konstribusi bagi siswa. Pengembangan kompetensi karir siswa dalam program bimbingan yang komprehensif dapat dikembangkan melalui beberapa layanan, yaitu (1) layanan dasar, (2) layanan responsif, (3) perencanaan individual, dan (4) dukungan system. Dengan adanya keempat layanan ini maka diharapkan akan menjadi panduan dalam melaksanan bimbingan karir untuk mengembangkan kompetensi siswa.

Hingga saat ini, kondisi sarana perencanaan karir di SMK $\mathrm{X}$ masih belum maksimal. Hal ini tampak dari proses administratif pendaftaran konseling yang masih bersifat manual sehingga kondisi ini terkadang mempersulit proses rekam data. Selain itu informasi mengenai lowongan pekerjaan masih melalui kertas-kertas yang ditempel di majalah dinding sekolah yang terkadang sering tidak update, serta minimnya minat para siswa untuk datang ke ruang Badan Konseling (BK) untuk menanyakan perihal perencanaan karir. Minimnya minat siswa untuk datang langsung ke pihak badan konseling karir disebabkan karena tingkat mobilitas tiap siswa yang tinggi sehingga mereka tidak memiliki waktu untuk membuat janji dengan pihak konselor. Dengan adanya perkembangan internet yang mudah digunakan dan tidak dibatasi ruang dan waktu, diharapkan dapat membantu menyelesaikan masalah ini.

\section{TINJAUAN PUSTAKA}

\section{A. Pengembangan Karir}

Pengembangan karir (career development) menurut Mondy ${ }^{[6]}$ meliputi aktivitas-aktivitas untuk mempersiapkan seorang individu pada kemajuan jalur karir yang direncanakan. Prinsip pengembangan karir dapat dijelaskan sebagai berikut.

1. Pekerjaan mempunyai pengaruh yang sangat besar terhadap pengembangan karir.

2. Bentuk pengembangan skill yang dibutuhkan ditentukan oleh permintaan pekerjaan yang spesifik.

3. Pengembangan akan terjadi hanya jika seorang individu belum memperoleh skill yang sesuai dengan tuntutan pekerjaan.

4. Waktu yang digunakan untuk pengembangan dapat direduksi/dikurangi dengan melakukan identifikasi rangkaian penempatan pekerjaan individu yang rasional.
Pengembangan karir (career development) meliputi perencanaan karir (career planning) dan manajemen karir (career management). Memahami pengembangan karir dalam sebuah organisasi membutuhkan suatu pemerikasaan atas dua proses, yaitu bagaimana masing-masing individu merencanakan, menerapkan tujuan-tujuan karirnya (perencanaan karir) dan bagaimana organisasi merancang dan menerapkan program pengembangan karir/manajemen karir.

\section{B. Perencanaan Karir}

Menurut Simamora (2001) ${ }^{[7]}$, perencanaan karir (career planning) adalah suatu proses saat individu dapat mengidentifikasi dan mengambil langkah-langkah untuk mencapai tujuan-tujuan karirnya. Perencanaan karir melibatkan pengindentifikasian tujuan-tujuan yang berkaitan dengan karir dan penyusunan rencana-rencana untuk mencapai tujuan tersebut. Sementara manajemen karir (career management) adalah proses organisasi memilih, menilai, menugaskan, dan mengembangkan para pegawainya guna menyediakan suatu kumpulan orang-orang yang berbobot untuk memenuhi kebutuhan-kebutuhan di masa depan.

Secara umum, tahapan perjalanan karir seseorang dapat dikelompokkan ke dalam lima tahapan, yaitu pertumbuhan, penjajakan, pemantapan, pemeliharaan, dan kemunduran. Pengelompokan itu didasarkan pada usia. (Muhammad Tasrifin, 2011) ${ }^{[8]}$

1. Dalam tahap pertumbuhan dialami oleh siswa yang berusia di bawah 15 tahun. Tahap ini diakhiri dengan adanya konsep tentang minat dan kemampuan dan mulai berpikir tentang alternatif keahlian.

2. Dalam usia 15 sampai 24 tahun, seseorang berada dalam tahap penjajakan. Dalam usia ini, siswa mulai menggali beberapa keahlian secara serius dan mulai mencoba untuk bekerja.

3. Pada usia 25 sampai 44 tahun, seseorang berada dalam tahap pemantapan. Siswa secara terus-menerus melakukan pengujian terhadap kemampuan yang dimilikinya dan mencoba untuk melakukan pekerjaan yang sesuai dengan minat dan bakatnya.

4. Dari usia 45 hingga 65 , seseorang sudah berada dalam tahap pemeliharaan yang artinya ia tidak lagi akan berusaha untuk mencari pekerjaan yang baru, melainkan akan mempertahankan pekerjaannya yang sekarang.

5. Dari usia 65 dan seterusnya, seseorang sudah masuk ke tahap kemunduran, dalam hal ini, dikatakan sudah tidak terikat pada suatu pekerjaan.

Dalam perencanaan karir ada lima syarat utama yang harus dipenuhi agar proses perencanaan tersebut dapat berjalan dengan baik. Kelima syarat tersebut adalah sebagai berikut.

1. Dialog, dalam hal ini siswa perlu diajak dialog untuk merencanakan karirnya.

2. Bimbingan, di tahap ini pihak sekolah harus memberikan perencanaan kepada siswanya agar bisa meniti karir dengan baik, karena tidak semua siswa memahami jalur karir.

3. Keterlibatan individual, pada tahap perencanaan karir, pihak sekolah harus melibatkan siswa dengan cara 
memberikan kesempatan untuk berbicara dan memberi masukan. Hal ini sama dengan syarat pertama yakni dialog.

4. Umpan balik, proses pemberian umpan balik akan terjadi jika ada dialog.

5. Mekanisme perencanaan karir, yang meliputi cara atau prosedur yang ditetapkan agar proses perencanaan karir dapat dilaksanakan dengan sebaik-baiknya.

\section{PHP}

PHP atau Hypertext Preprocessor adalah bahasa skrip yang dapat ditanamkan atau disisipkan ke dalam HTML. PHP banyak dipakai untuk memprogram situs web dinamis. PHP dapat digunakan untuk membangun sebuah CMS (Content Management System).

\section{CodeIgniter}

CodeIgniter adalah aplikasi open source yang berupa framework dengan model MVC (Model, View, Controller) untuk membangun website dinamis dengan menggunakan PHP

\section{E. MySQL}

MySQL adalah sebuah perangkat lunak sistem manajemen basis data SQL (database management system) atau DBMS yang multithread, multiuser. Menurut Pressman model proses untuk rekayasa perangkat lunak dipilih berdasarkan sifat aplikasi maupun proyeknya, metode dan alatalat bantu yang dipakai, serta kontrol dan penyampaian yang dibutuhkan. Salah satu model proses untuk rekayasa perangkat lunak adalah model waterfall. Nama metode waterfall sebenarnya adalah Linear Sequential Model. Model ini sering disebut dengan classic life cycle, merupakan model yang paling banyak dipakai didalam Software Engineering (SE).

Model ini melakukan pendekatan secara sistematis dan urut mulai dari level kebutuhan sistem lalu menuju ke tahap analisis, desain, pengkodean, pengujian, dan pemeliharaan. Model ini disebut dengan waterfall karena tahap demi tahap yang dilalui harus menunggu selesainya tahap sebelumnya dan berjalan berurutan. Sebagai contoh tahap desain harus menunggu selesainya tahap sebelumnya yaitu tahap requirement. Secara umum tahapan pada model waterfall dapat dilihat pada Gambar 1.

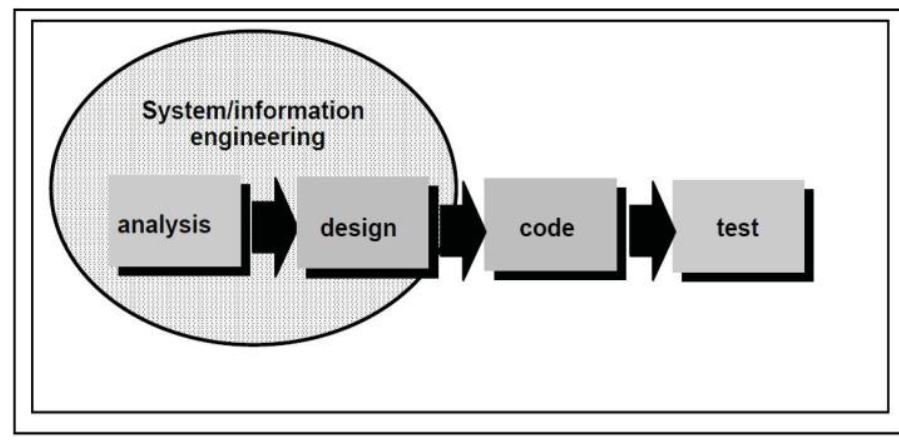

Gambar 1 Model Waterfall (Pressman, 2010)

Berikut adalah penjelasan dari tahap-tahap yang dilakukan di dalam model waterfall sesuai dengan Gambar 1 diatas:

\section{Analysis}

Seluruh kebutuhan software harus bisa didapatkan dalam fase ini, termasuk di dalamnya kegunaan software yang diharapkan pengguna dan batasan software. Informasi ini pada umumnya dapat diperoleh melalui wawancara, survei atau diskusi dengan pengguna. Informasi tersebut dirinci, dianalisis, dan dijadikan dokumentasi spesifikasi kebutuhan pengguna untuk digunakan pada tahap selanjutnya.

\section{Design}

Tahapan ini dilakukan sebelum mengerjakan pengkodean. Tahap ini bertujuan untuk memberikan gambaran apa yang seharusnya dikerjakan dan bagaimana tampilan sistem. Tahapan ini juga dapat membantu dalam mendefinisikan kebutuhan hardware, sistem, dan arsitektur sistem secara keseluruhan.

\section{Coding}

Tahapan ini dilakukan pemrograman untuk membuat software yang akan dipecah menjadi modul-modul kecil. Modul-modul kecil itu nantinya akan digabungkan dalam tahap berikutnya. Tahap ini juga dilakukan proses pemeriksaaan terhadap modul yang telah dibuat untuk mengetahui keseluruhan fungsi yang diinginkan.

\section{Testing}

Pada tahap terakhir ini dilakukan proses penggabungan modul-modul yang sudah dibuat dan dilakukan pengujian untuk mengetahui kesesuaian antara perangkat lunak dengan model. Hal itu dilakukan untuk menjamin tidak adanya kesalahan yang terjadi pada sistem secara keseluruhan. Apabila ada kesalahan yang terjadi maka dilakukan proses pemeliharaan guna memperbaiki kesalahan yang tidak ditemukan pada tahap sebelumnya. Perbaikan implementasi unit sistem dan peningkatan jasa sistem akan dianggap sebagai kebutuhan baru.

TABEL I

PERBANDINGAN ANTARMODEL

\begin{tabular}{|l|l|l|l|l|}
\hline No. & Faktor & Waterfall & Spiral & Incremental \\
\hline 1 & $\begin{array}{l}\text { Proyek } \\
\text { dengan } \\
\text { ukran risiko }\end{array}$ & Kecil & Sedang & Besar \\
\hline 2 & $\begin{array}{l}\text { Ukuran } \\
\text { software }\end{array}$ & Kecil & Besar & Besar \\
\hline 3 & $\begin{array}{l}\text { Jenis } \\
\text { Aplikasi }\end{array}$ & Biasa & Agak Biasa & Tidak Biasa \\
\hline 4 & $\begin{array}{l}\text { Fleksibel } \\
\text { terhadap } \\
\text { perubahan } \\
\text { waktu }\end{array}$ & Rendah & $\begin{array}{l}\text { Perubahan } \\
\text { awal }\end{array}$ & $\begin{array}{l}\text { Perubahan } \\
\text { selama } \\
\text { proyek } \\
\text { berlangsung }\end{array}$ \\
\hline 5 & $\begin{array}{l}\text { Keterlibatan } \\
\text { konsumen }\end{array}$ & Rendah & Sedang & Tinggi \\
\hline
\end{tabular}

Dari Tabel 1 terlihat bahwa model waterfall memiliki kesesuaian dengan spesifikasi sistem yang akan dibuat. Sistem ini tidak fleksibel terhadap perubahan waktu dan tidak terlalu banyak melibatkan konsumen dalam proses pembuatannya. Model waterfall juga memiliki kelebihan dari model lainnya, kelebihannya adalah ketika semua kebutuhan sistem dapat didefinisikan secara utuh, eksplisit, dan benar pada awal 
project, maka aplikasi dapat berjalan dengan baik dan tanpa masalah. Alasan lain menggunakan metode waterfall adalah karena penelitian ini memiliki waktu yang cukup pendek sehingga definisi kebutuhan harus diperjelas pada awal project. Selain itu, walaupun ada literasi dalam proses, dokumentasi perancangan tetap menggunakan metode waterfall untuk tiap tahapanya.

\section{F. Unified Modeling Language}

Unified Modelling Language (UML) adalah sebuah "bahasa" yang menjadi standar dalam industri untuk visualisasi, merancang dan mendokumentasikan sistem piranti lunak. UML menawarkan sebuah standar untuk merancang model sebuah sistem. Dengan menggunakan UML dapat dibuat model untuk semua jenis aplikasi piranti lunak, dimana aplikasi tersebut dapat berjalan pada piranti keras, sistem operasi dan jaringan apapun, serta ditulis dalam bahasa pemrograman apapun. Tetapi karena UML juga menggunakan class dan operation dalam konsep dasarnya, maka UML lebih cocok untuk penulisan piranti lunak dalam bahasa-bahasa berorientasi objek

\section{Metodologi Penelitian}

\section{A. Model Konseptual}

Sebelum merumuskan kerangka penelitian, berikut ini akan dijelaskan pembentukan model konseptual untuk menggambarkan kerangka pemikiran yang digunakan dalam penelitian ini. Model konseptual dari penelitian ini dapat dilihat pada Gambar 2.
Aplikasi perencanaan karir online di SMK X dirancang untuk meningkatkan layanan perencanaan karir bagi siswa di SMK X Berdasarkan Gambar 2, aplikasi perencanaan karir online ini akan dibangun atas dasar studi literatur, dan latar belakang yang ada yaitu keadaan internal perencanaan karir di SMK X dilakukan dengan cara pemberian materi oleh para guru setiap sekali dalam seminggu dan itu hanya terbatas pada teori-teori mengenai karir. Melihat hasil kuesioner dari para siswa yang menyebutkan bahwa siswa belum sepenuhnya mengetahui dan memahami bagaimana dunia kerja yang akan siswa hadapi nantinya, kemudian masih minimnya minat siswa dalam mengunjungi website perencanaan karir, dan juga trend yang saat ini berkembang adalah teknologi dalam hal ini internet yang sudah menjadi kebutuhan bagi setiap individu termasuk para siswa.

Output yang diharapkan dengan adanya aplikasi perencanaan karir online ini diantaranya terciptanya aplikasi perencanaan karir online yang informatif,efektif, dan efisien sehingga dapat meningkatkan layanan perencanaan karir. Seluruh siswa nantinya diwajibkan untuk mengakses website ini terkait materi dan penugasan dari materi perencanaan karir di kelas tiap minggunya.

Aplikasi perencanaan karir online dirancang dengan mengkolaborasikan teknologi berbasis web. Penggunaan teknologi berbasis web dipilih karena teknologi ini dapat diakses dari mana saja dan kapan saja sehingga tidak banyak menyita waktu para siswa.

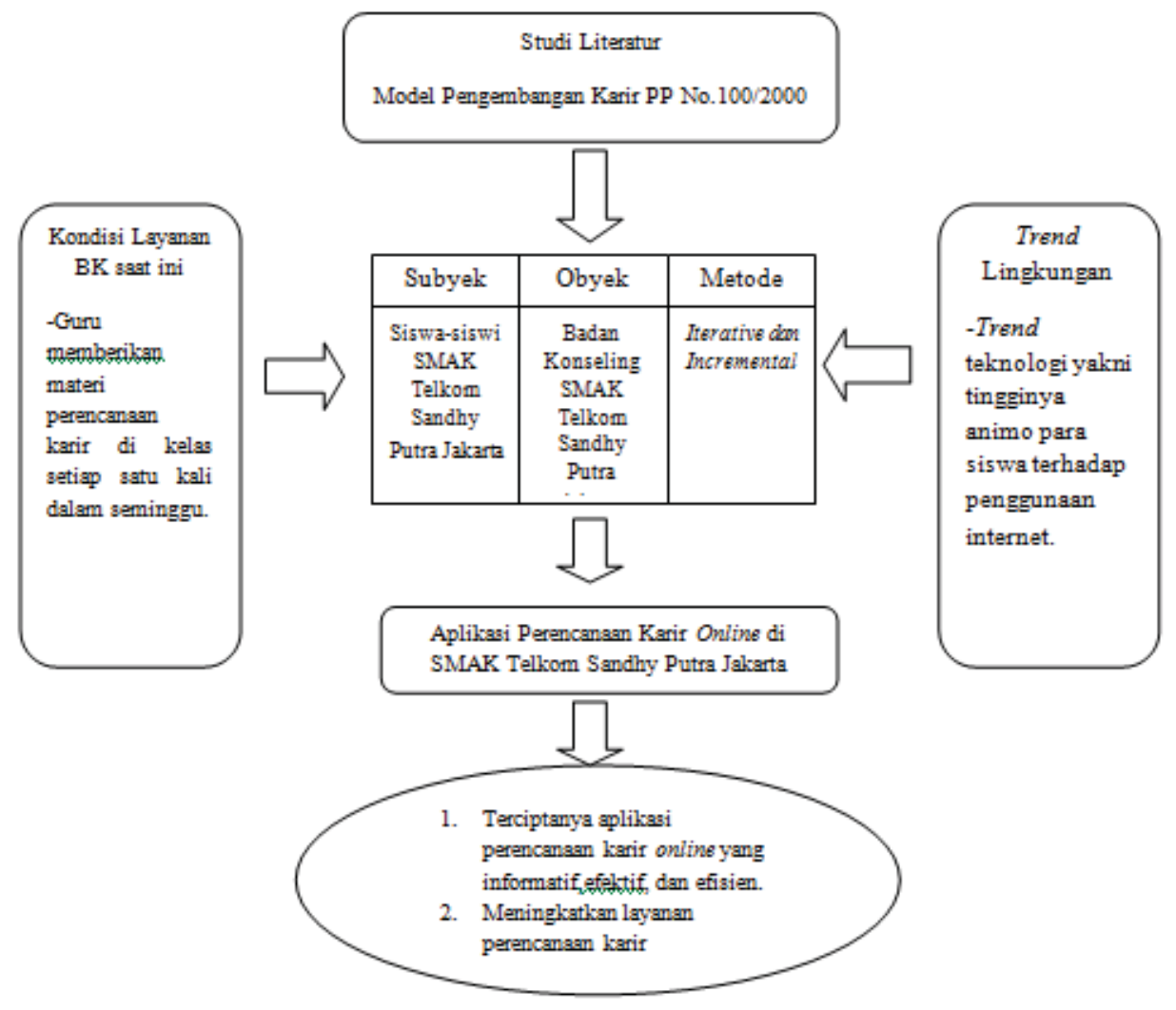

Gambar 2 Model Konseptual Penelitian 
B. Sistematika Penelitian

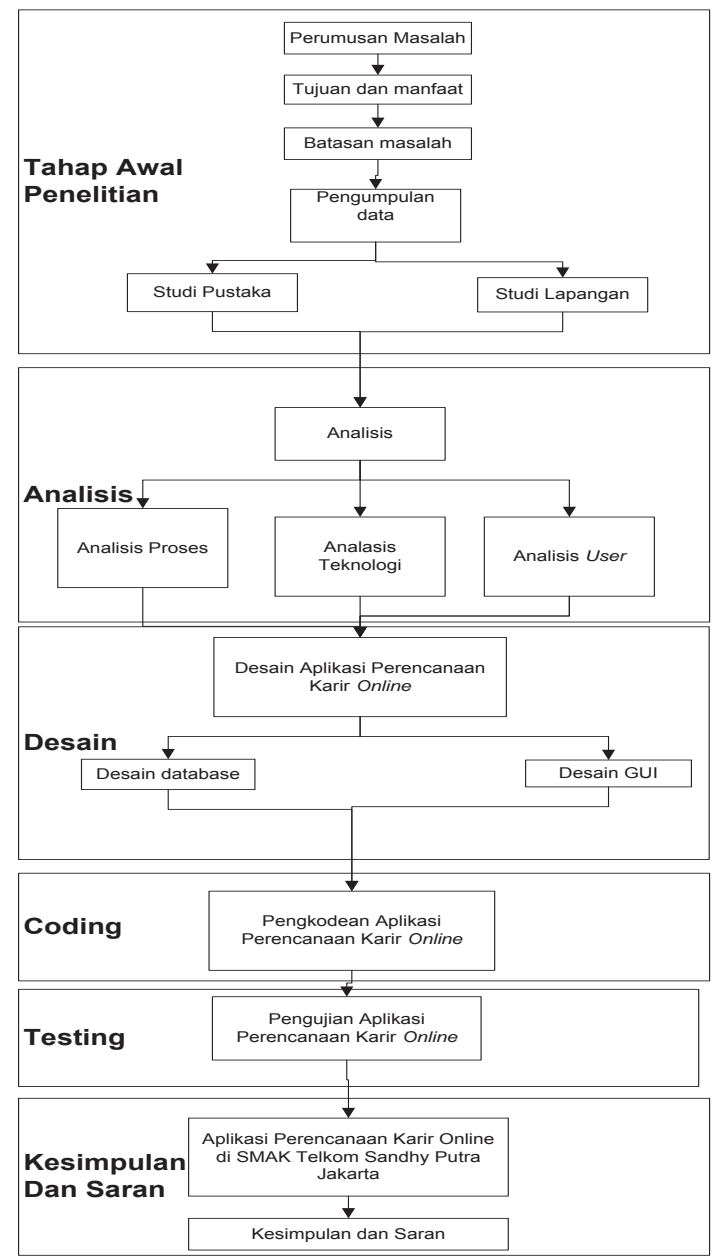

Gambar 3 Model Konseptual Penelitian

Berdasarkan Gambar 3, sistematika penelitian akan meliputi empat tahapan, yaitu sebagai berikut.

1. Requirement Analysis

Requirement analysis merupakan tahap awal dalam penelitian ini. Proses dimulai dari identifikasi masalah yang ada pada perencanaan karir SMK X untuk kemudian dilakukan studi pendahuluan terhadap masalah yang nantinya akan dijadikan bahan penelitian. Studi pendahuluan pada penelitian sendiri akan dilakukan dengan 2 cara yaitu dengan literatur dan studi lapangan. Studi literatur sendiri adalah proses pencarian referensi dengan menggunakan buku referensi ataupun jurnal baik yang berbentuk hardcopy ataupun softcopy. Hal itu dilakukan untuk mengetahui informasi berdasarkan penelitian sebelumnya yang telah dilakukan oleh para ahli sedangkan studi lapangan dilakukan untuk mendapatkan informasi secara valid langsung dari objek yang akan dijadikan penelitian dengan melakukan wawancara secara langsung kepada bagian perencanaan konseling SMK X Setelah studi pendahuluan tersebut dilakukan, maka kemudian akan dapat ditentukan rumusan masalah, tujuan penelitian, manfaat penelitian serta batasan masalah yang akan diselesaikan. Setelah kebutuhan penelitian telah didapatkan, maka selanjutnya dilakukan proses analisis. Proses analisis terdiri dari proses bisnis, analisis kebutuhan pengguna, dan analisis kebutuhan sistem. Hasil dari tiga kegiatan tersebut nantinya akan menjadi dasar untuk pembuatan desain sistem.

2. Design

Design sendiri merupakan tahapan pembentukan desain proses bisnis dan proses sistem dari menerjemahkan kebutuhan yang telah didapat pada tahap sebelumnya. Tujuan dari tahap desain ini adalah untuk mempermudah proses pengkodean program agar aplikasi yang dibuat nanti sesuai dengan kerangka / arsitektur sistem yang diinginkan.

3. Coding

Coding adalah tahap dimulainya proses pengkodean program dengan menggunakan basis PHP framework codeigniter yang merupakan bahasa pemrograman yang berorientasi objek.

4. Implementation

Implementation adalah tahap dimana sistem akan diuji apakah sistem tersebut layak untuk digunakan pada proses perencanaan karir online. Tahap ini dimulai dari pengujian fungionalitas yaitu menguji semua fitur yang terdapat pada aplikasi. Tahap selanjutnya adalah pengujian perencanaan karir online yaitu tahap dimana sistem akan diuji coba oleh user. Tahap pengujian terakhir adalah pengujian muatan yaitu tahap dimana aplikasi akan diuji coba dengan cara diakses oleh banyak user dalam waktu bersamaan. Setelah aplikasi memenuhi kriteria yang diinginkan user, barulah aplikasi akan diimplementasikan pada proses perencanaan karir online SMK X .

\section{ANALISIS DAN PERANCANGAN}

\section{A. Gambaran Proses Bisnis Organisasi}

SMK X merupakan sekolah menengah atas kejuruan yang memiliki fokus studi di bidang telekomunikasi. Sekolah ini didirikan pada tahun 1992 atas dasar ide dari Menteri Pariwisata, Pos dan Telekomunikasi dengan empat bidang kejuruan, antara lain Teknik Transmisi, Teknik Switching, Teknik Jaringan Akses dan Teknik Informatika.

Sejak sekolah ini berdiri, terdapat BK yang menjadi wadah bagi para siswa untuk mengembangkan diri, menggali potensi dan hal lainnya yang berkaitan dengan siswa itu sendiri. Akan tetapi, terkait dengan perencanaan karir dirasa masih belum terlalu menunjang, padahal karir bagi setiap individu perlu dipersiapkan dengan matang sejak dini khususnya bagi siswa sekolah kejuruan yang notabene setelah lulus mayoritas siswanya dipersiapkan untuk langsung terjun ke dunia kerja.

\section{B. Deskripsi Sistem}

Sistem yang dibuat merupakan sistem yang mengintegrasikan beberapa fungsi terkait dengan perencanaan karir bagi siswa. Ada empat user dengan hak akses berbeda, yaitu sebagai berikut. 
1. Admin BK dengan hak aksesnya adalah menambah artikel-artikel sekaligus merubah dan menghapusnya. Selain itu user ini juga yang menambahkan serta menghapus baik itu data siswa dan data guru BK. Hak akses lainnya yakni memasukkan informasi lowongan kerja.

2. Guru BK memiliki hak akses untuk melihat profil siswa sekaligus memasukkan data hasil psikotest dan mengirimkan pesan kepada siswa. Guru BK juga dapat mengunggah materi pelajaran serta memasukkan info lowongan kerja.

3. User yang ketiga adalah siswa dimana hak aksesnya antara lain melihat artikel, berkirim pesan dengan guru BK serta dapat mengunduh materi pelajaran yang diunggah oleh guru BK. Selain itu, siswa juga dapat melihat hasil psikotest.

4. Admin merupakan user terakhir yang memiliki hak akses untuk menambahkan lowongan kerja sekaligus dapat melihat siapa-siapa saja siswa yang mencalonkan diri menjadi karyawan di lowongan yang siswa informasikan. Secara garis besar, sistem ini memiliki fungsi untuk mengintegrasikan layanan yang dimiliki oleh BK khususnya dalam perencanaan karir bagi siswa.

C. Analisis Proses Bisnis Terdahulu

Proses bisnis terdahulu pada perencanaan karir online di SMK $X$ ini dibagi menjadi dua bagian di antaranya: perencanaan karir dan lowongan pekerjaan. Untuk proses yang pertama yaitu perencanaan karir digambarkan melalui Gambar 4 berikut ini:

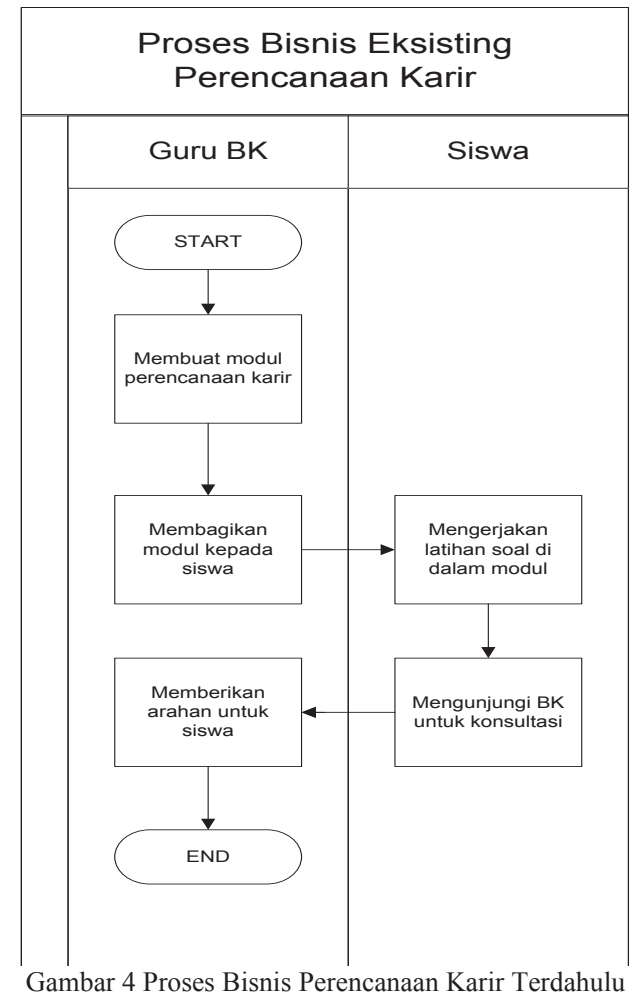

D. Analisis Kebutuhan Aplikasi Usulan
Dengan melihat kekurangan dari kondisi terdahulu perencanaan karir dan informasi lowongan kerja, maka pihak BK memerlukan suatu sistem yang dapat mempermudah jalannya kedua aktivitas tersebut. Proses bisnis usulan yang yang dirancang adalah seperti Gambar 5.

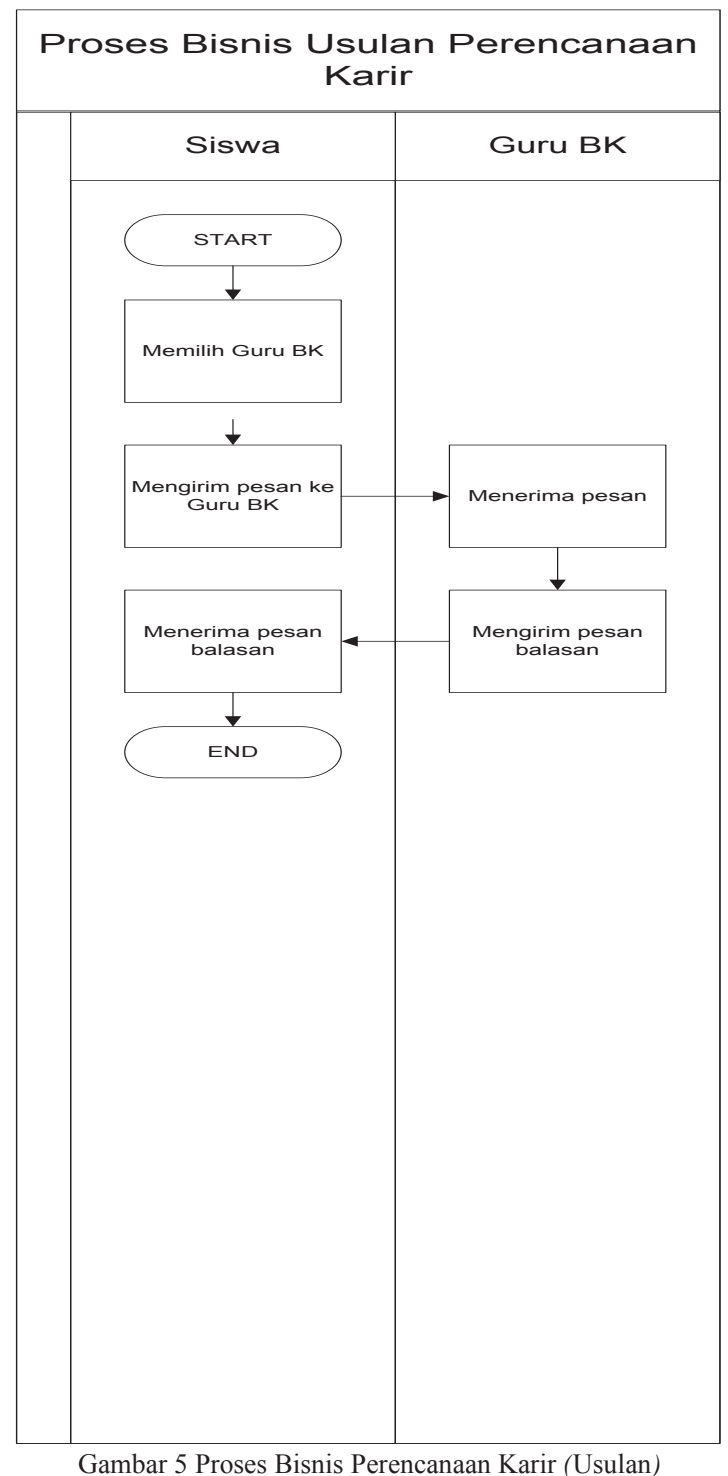

\section{E. Kebutuhan Sistem}

Dalam pembuatan Aplikasi perencanaan karir online ini dibutuhkan beberapa fitur yang dapat menangani permasalahan seperti yang disebutkan dalam rumusan masalah. Berdasarkan wawancara terhadap pihak BK SMK X ada beberapa fitur yang menjadi kebutuhan utama diantaranya:

1. sistem memiliki fitur perencanaan karir online;

2. sistem memiliki fitur lowongan kerja secara online dan terintegrasi dengan perusahaan tertentu;

3. sistem dapat diakses melalui web.

F. Desain Sistem

Pada tahap desain sistem, perancangan desain dibagi menjadi dua jenis desain sistem yaitu desain perancangan 
proses sistem dan desain perancangan sistem database. Adapun pendekatan yang digunakan adalah pendekatan berorientasi objek menggunakan alat pemodelan UML Desain perancangan proses sistem akan menggambarkan beberapa diagram UML yaitu: Diagram Use Case, Diagram Class, Diagram Activity, Diagram Sequence.

\section{HASIL DAN PENGUJIAN}

\section{A. Perencanaan dan Deskripsi Sistem}

Aplikasi perencanaan karir online SMK X ini bertujuan untuk memberi kemudahan bagi siswa yang akan melakukan konsultasi dengan pihak BK. Untuk menguji fungsionalitas fitur web yang telah dibuat maka perlu dilakukan pengujian untuk memastikan bahwa semua fitur berfungsi. Dalam melakukan pengujian perangkat lunak yang akan digunakan yaitu:

1. Microsoft Windows 7 sebagai sistem operasinya;

2. MySQL sebagai basis data tempat penyimpanan data-data registrasi;

3. XAMPP 1.7.3 sebagai paket webserver dan database

4. Google Chrome 15.1 sebagai browser tempat menjalankan kode program yang dibuat;

5. Macromedia Dreamweaver 8 sebagai tempat untuk melakukan pengkodean dan mempermudah dalam melakukan pengecekan apabila ada kode program yang salah;

6. tools pengujian lain yang direncanakan.

Beberapa perangkat keras yang akan digunakan yaitu:

1. Notebook ACER Aspire $2920 \mathrm{Z}$ yang dianggap sebagai server dengan spesifikasi Intel Dual-Core processor T2390;

2. koneksi internet.

Adapun sumber daya manusia yang ikut dilibatkan dalam melakukan pengujian ini diantaranya adalah sebagai berikut.

1. Tester

Terdiri dari tiga orang penguji yang terlibat dalam menggunaan aplikasi perencanaan karir online yaitu:

a. satu orang penguji bertugas menjadi siswa;

b. satu orang penguji bertugas menjadi admin;

c. satu orang penguji bertugas menjadi Guru BK.

2. Operator

Terdiri atas satu orang operator yang bertugas mencatat aktivitas dari setiap user/tester yang melakukan pengujian dan menganalisis kelemahan yang terjadi selama proses pengujian berlangsung.

\section{B. Teknis Pengujian}

Pengujian dari aplikasi yang telah dibuat adalah dengan metode Black Box Testing, yaitu metode pengujian aplikasi tanpa melihat kode program. Pengujian hanya dilakukan untuk memastikan fungsionalitas program berjalan seperti yang diharapkan. Proses dalam teknis pengujian ini terdiri atas beberapa tahapan, yaitu sebagai berikut.

1. Persiapan Prosedural
Pada persiapan prosedural, proses yang akan dilakukan untuk melakukan pengujian diantaranya adalah:

a. mempersiapkan perangkat keras dan lunak yang dibutuhkan, serta memastikan aplikasi siap untuk diuji;

b. menentukan tester serta operator untuk pengujian;

c. menentukan metode testing pengujian yang akan dilakukan, dalam hal ini pengujian yang akan dilakukan adalah black box testing yaitu berupa functionality test (pengujian berdasarkan fungsionalitas aplikasi);

d. menentukan indikator keberhasilan agar tujuan dalam pembuatan sistem tercapai.

2. Persiapan Perangkat Keras

Persiapan perangkat keras (hardware) yang akan digunakan dalam pegujian diantaranya adalah:

a. Notebook ACER Aspire $2920 Z$ yang dianggap sebagai server dengan spesifikasi Intel Dual-Core processor T2390;

b. koneksi internet.

3. Persiapan Perangkat Lunak

Persiapan perangkat lunak (software) yang akan digunakan dalam pengujian diantaranya adalah:

a. melakukan Instalasi perangkat lunak (software) yang dibutuhkan seperti Macromedia Dreamweaver 8 dan XAMPP 1.7.3;

b. melakukan konfigurasi untuk database serta web service.

4. Pelaksanaan

1) Pelaksanaaan pengujian ini akan dilakukan dengan menguji sistem secara keseluruhan. Pengujian ini melibatkan pengujian terhadap semua fungsionalitas yang terdapat pada aplikasi perencanaan karir online SMK X.

5. Pelaporan Hasil

2) Laporan dari hasil pengujian ini adalah berupa dokumentasi hasil pengujian untuk mengetahui performa aplikasi yang telah dibuat.

6. Pengujian Fungsionalitas (Functionality Testing)

3) Pengujian fungsionalitas ini dilakukan untuk menguji fungsionalitas aplikasi sesuai dengan spesifikasi yang telah ditetapkan sebelumnya.

\section{User Acceptance Testing}

Pengujian penerimaan pengguna ini dilakukan untuk menguji kelayakan aplikasi sesuai dengan sudut pandang pengguna aplikasi. Pengujian ini menggunakan form yang berisi penilaian tampilan dan kinerja aplikasi secara keseluruhan. Rencana pengujian penerimaan pengguna ini menggunakan empat skala seperti yang digambarkan melalui Tabel II berikut ini. 
TABEL II

Rencana Pengujian PenerimaAn Pengguna

\begin{tabular}{|l|l|}
\hline \multicolumn{1}{|c|}{ Skala } & \multicolumn{1}{c|}{ Definisi } \\
\hline Design & $\begin{array}{l}\text { Menggambarkan daya tarik desain } \\
\text { antarmuka pengguna (user interface) } \\
\text { sistem yang dibuat. }\end{array}$ \\
\hline Reliability & $\begin{array}{l}\text { Mengukur kemampuan aplikasi untuk } \\
\text { mengelola proses perencanaan karir } \\
\text { dengan cepat. Serta menjaga informasi } \\
\text { pribadi pendaftar agar tetap aman. }\end{array}$ \\
\hline Responsiveness & $\begin{array}{l}\text { Mengukur kemampuan aplikasi untuk } \\
\text { memberikan informasi dan layanan } \\
\text { yang tepat kepada pelanggan. }\end{array}$ \\
\hline Trust & $\begin{array}{l}\text { Mengukur tingkat kepercayaan siswa } \\
\text { untuk melakukan perencanaan karir } \\
\text { secara online. }\end{array}$ \\
\hline
\end{tabular}

Kelas pengujian penerimaan pengguna digambarkan dalam sebuah form yang nantinya akan diberikan kepada pihak sekolah dan juga calon pendaftar. Form tersebut dapat dilihat pada tabel berikut ini.

TABEL III

FORM USER ACCEPTANCE TESTING

\begin{tabular}{|c|c|c|c|}
\hline \multirow{2}{*}{ Skala } & \multirow{2}{*}{ Pertanyaan } & \multicolumn{2}{|c|}{ Jawaban } \\
\hline & & Ya & Tidak \\
\hline \multirow[t]{3}{*}{ Design } & $\begin{array}{l}\text { Apakah tampilan aplikasi } \\
\text { secara keseluruhan menarik? }\end{array}$ & $\sqrt{ }$ & \\
\hline & $\begin{array}{l}\text { Apakah menu dan fungsi } \\
\text { dalam aplikasi dapat } \\
\text { dimengerti dengan baik? }\end{array}$ & $\sqrt{ }$ & \\
\hline & $\begin{array}{l}\text { Apakah informasi yang } \\
\text { diberikan aplikasi cukup? }\end{array}$ & $\sqrt{ }$ & \\
\hline Reliability & $\begin{array}{l}\text { Apakah aplikasi dapat } \\
\text { menangani proses konsultasi } \\
\text { dengan mudah dan akurat? }\end{array}$ & $\sqrt{ }$ & \\
\hline \multirow[t]{2}{*}{$\begin{array}{l}\text { Responsive } \\
\text { ness }\end{array}$} & $\begin{array}{l}\text { Apakah aplikasi dapat } \\
\text { memberikan kemudahan } \\
\text { dalam melakukan bimbingan } \\
\text { di BK SMK X? }\end{array}$ & $\sqrt{ }$ & \\
\hline & $\begin{array}{l}\text { Apakah aplikasi dapat } \\
\text { memberikan respon yang } \\
\text { cepat ketika di akses? }\end{array}$ & $\sqrt{ }$ & \\
\hline \multirow[t]{2}{*}{ Trust } & $\begin{array}{l}\text { Apakah aplikasi dapat } \\
\text { dipercaya sebagai media } \\
\text { melakukan bimbingan karir } \\
\text { secara online? }\end{array}$ & $\sqrt{ }$ & \\
\hline & $\begin{array}{l}\text { Apakah aplikasi dapat } \\
\text { menyajikan informasi yang } \\
\text { transparan mengenai karir? }\end{array}$ & $\sqrt{ }$ & \\
\hline
\end{tabular}

Form user acceptance testing ini berisi beberapa pertanyaan yang dikategorikan dalam tiap skala pengujian yang telah ditentukan sebelumnya.
D. Verifikasi Hasil Pengujian

Berdasarkan hasil pengujian fungsionalitas dan penerimaan pengguna yang telah dilakukan, maka hasil yang didapatkan adalah sebagai berikut.

1. Seluruh fungsi yang diujikan pada sistem dapat berjalan dengan baik. Setiap input data yang dimasukkan dapat diterima dengan baik, dan berhasil memberikan output data yang diharapkan.

2. Aplikasi yang dibuat dapat memenuhi semua fungsi yang dibutuhkan oleh siswa dan BK.

3. Aplikasi yang telah dibuat memiliki tampilan yang menarik dan mudah dimengerti oleh user.

\section{KESIMPULAN DAN SARAN}

Setelah pembuatan aplikasi karir online berbasis web dengan menggunakan metode waterfall dan dilakukan pengujian langsung kepada target user serta wawancara, yaitu kepada siswa sekolah, pihak bimbingan karir dan tenaga pendidik, maka diperoleh kesimpulan bahwa aplikasi perencanaan karir online yang dapat membantu pihak sekolah, yaitu:

1. melalui aplikasi ini, baik proses perencanaan karir maupun proses konseling siswa dapat dilakukan dengan maksimal;

2. penyebaran informasi lowongan kerja lebih praktis;

3. Tersedianya informasi mengenai karir secara berkala.

Berdasarkan penelitian yang telah dilakukan, adapun hal yang perlu dikembangkan adalah sebagai berikut.

1. Fitur untuk guru BK dilengkapi sesuai dengan tugas guru BK.

2. Adanya fitur informasi berbagai kampus beserta program studi untuk siswa yang akan melanjutkan ke jenjang pendidikan yang lebih tinggi yakni perkuliahan.

3. Aplikasi dapat terintegrasi melalui SMS Gateway dengan para orangtua siswa.

4. Khusus untuk fitur lowongan kerja, dilengkapi dengan kode lowongan sehingga para siswa tidak bisa mendaftar jika sudah melewati batas yang ditentukan oleh perusahaan.

5. Adanya laporan tertulis mengenai indeks poin pelanggaran dan tingkat prestasi siswa di sekolah.

6. Sistem tidak hanya mengakomodasi Perencanaan Karir di satu sekolah saja melainkan seluruh SMK Telkom yang tersebar di beberapa wilayah di Indonesia.

\section{DAFTAR PUSTAKA}

[1] Hardjono Notodiharjo. (1990). Pendidikan tinggi dan tenaga kerja tingkat tinggi di Indonesia. Jakarta: Universitas Indonesia

[2] Bambang Wahyudi, 2002, Manajemen Sumber Daya Manusia. Penerbit Sulita Bandung

[3] Peraturan Pemerintah Nomor 29 Tahun 1990 
[4] Affiandary, Chandra, 2010, Program Bimbingan Karir Untuk Meningkatkan Kematangan Karir Siswa Menengah Atas, Bandung, Penelitian, Universitas Pendidikan Indonesia.

[5] Gysbers, N.C \& Henderson, P. (2006). Developing and Managing Your School Guidance and Counselling Program (fourth edition). US.ACA

[6] Mondy R., Wayne. Manajemen Sumber Daya Manusia Edisi 10, Erlangga, Jakarta.

[7] Simamora, Henry, 2006 Sumber Daya Manusia Edisi 3, Yogyakarta, STIE YPN.

[8] Tasrifin, Muhammad. (2011) Manajemen Karir. Jurnal Fakultas Ekonomi Univ Narotama. Surabaya

[9] Pressman, R.S. (2010), Software Engineering: a practitioner's approach, McGraw-Hill, New York. 